\title{
Dossiê
}

Dramaturgia Musical

Teatro para bebês: uma experiência de escuta na construção dramatúrgica cênica-musical

Fernanda Alvarenga Cabral 


\section{Teatro para bebês: uma experiência de escuta na construção dramatúrgica cênica-musical ${ }^{1}$}

Fernanda Alvarenga Cabral

Atriz, cantora, pesquisadora fernandacabralweb@gmail.com

Resumo: O teatro para bebês já ocupa um lugar singular no teatro contemporâneo. Seu estudo está vinculado ao ensino na primeira infância, mas também ao desenvolvimento de outras formas de se pensar a sua própria poética em cena. O sonoro-musical é parte da construção da atividade de escuta que, por sua vez, acompanha as diferentes etapas de elaboração da obra teatral, assim como encontra ecos de ressonância na "construção do imaginário poético" do artista-criador e em seu processo de criação dramatúrgica. Um estudo que trata da criação cênica aliada à construção de uma "escuta-ativa" entre intérprete e público, simultaneamente, durante a sua elaboração e recepção, tendo o sonoro-musical como eixo constituinte - o leitmotiv - do próprio espetáculo.

Palavras-chave: Processos Criativos, Dramaturgia Musical, Escuta, Teatro para bebês, Primeira Infância.

Abstract: Theatre for babies already occupies a unique place in the contemporary theater. This study is linked to the teaching activity in early childhood, but also to the development of other ways of thinking his own poetic scene. The sound-music is part of the construction of the listening activity which, in turn, follows the different stages of drafting the play as well as finds resonance echoes in the "construction of the poetic imagination", the artistcreator and its dramaturgical creation process. A study that deals with scenic creation coupled with the construction of a "active listening" between performer and audience, both during its preparation and reception, and the sound-musical as a constituent axis the leitmotif - the show itself.

Keywords: Creative Processes, Musical dramaturgy, Listening, Theater babies, Early Childhood.

1 N.E. Texto elaborado a partir de sua dissertação de mestrado Teatro para bebês: Processos criativos, Dramaturgia e escuta. (PPG-Arte, Universidade de Brasília, 2016). 


\section{O Teatro para Bebês}

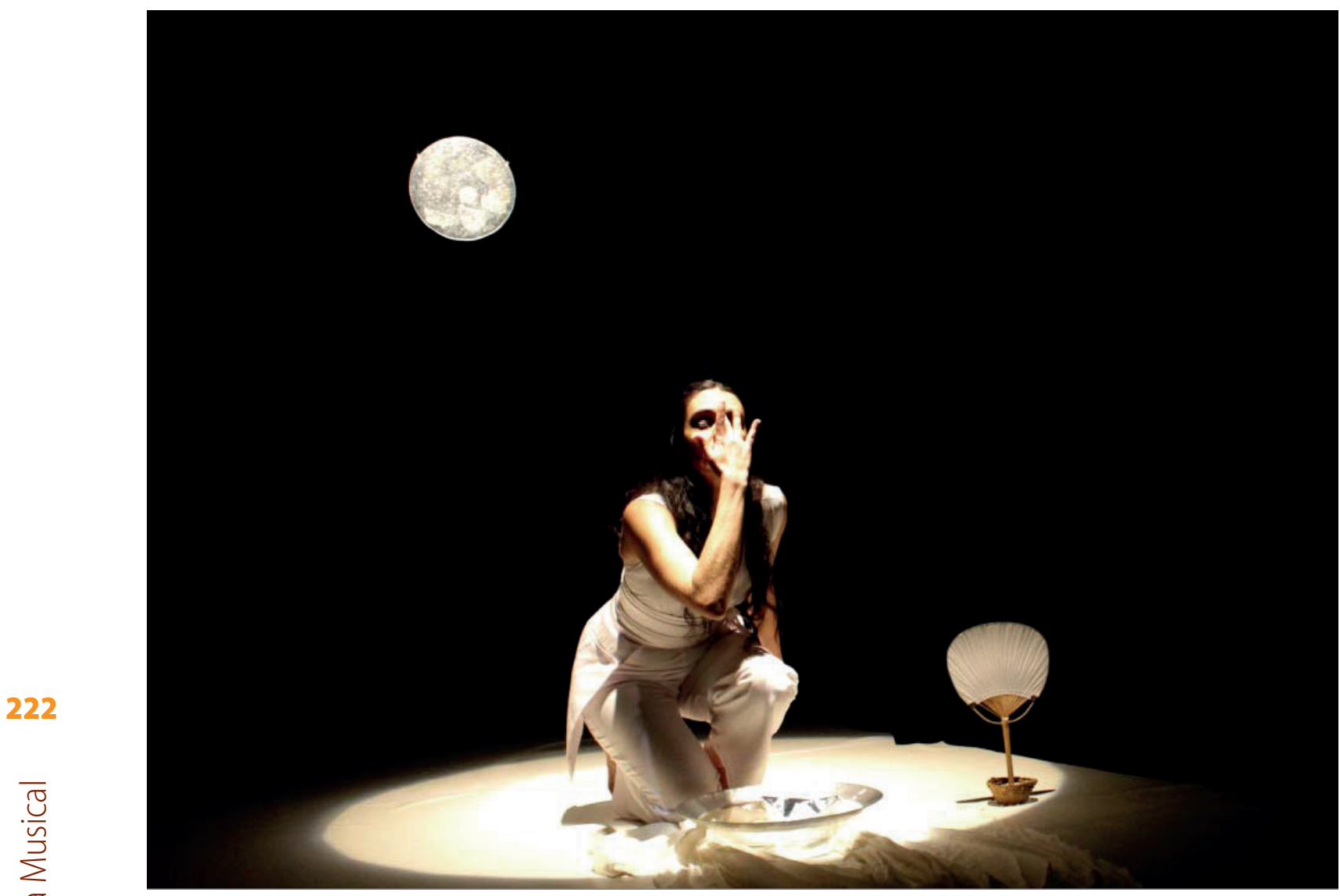

Foto do Espetáculo O Farol² / Fonte: André Amaro

O chamado "teatro para bebês" ou "teatro para a primeira infância" é uma arte produzida por meio de diferentes pesquisas dramatúrgicas e propostas estéticas, podendo integrar diferentes linguagens ao próprio teatro, como a dança, a música e/ou as artes plásticas. É destinado a um público com faixa etária entre seis e trinta e seis meses e possui duração de 20 a 40 minutos.

Quando nomeamos o chamado "teatro para bebês", referimo-nos a uma expressão teatral contemporânea iniciada na França, no inicio dos anos 1990, a partir de algumas experiências isoladas nos anos 1980. Consideramos o ano de 1992 como a data de batismo teatral dessa tão jovem expressão artística, ocasião em que foi realizada, na cidade de Marne-la-Vallée-Maubuée, a primeira bienal, intitulada Bienal das Artes para Crianças de 0 a 7 anos (CABANIS; JANELLE, 1993, p. 5).

Uma poética cênica que inicia seu jogo ainda no hall de entrada, no momento de "acolhimento", antes mesmo da execução do espetáculo, quando as famílias de pais e bebês são recebidas no espaço externo ao local de apresentação da peça. Conforme afirma o autor Flávio Desgranges: "um projeto de formação de espectadores, por sua vez, cuida

2 Apresentação do espetáculo O Farol (Cia. Studio Sereia) no Teatro Plinio Marcos da Funarte, em Brasília, no dia 9 de julho de 2016 dentro da programação do III Festival Primeiro Olhar do DF. Para mais informação veja: http://studiosereia.wixsite.com/teatroparabebes. 
não somente de pôr o espectador diante do espetáculo, mas trata também da intimidade desse encontro, estreitando laços afetivos, afinando a sintonia, mediando a relação dialógica entre espectador e obra de arte" (2011, p. 157).

A partir desse momento e lugar de encontro, inicia-se a construção de uma dramaturgia da escuta, de uma dramaturgia que surge da relação de intersubjetividade entre o artista e o público, onde o aspecto sonoro-musical pode tornar-se o eixo condutor na elaboração e recepção do espetáculo.

O teatro para bebês surge do desejo de sussurro, das palavras incógnitas que, ao serem pronunciadas no jogo onomatopaico que as conforma, comunicam-se com o público. A dramaturgia sonora, como componente criativo na elaboração de uma obra teatral, torna-se assim uma aventura no imaginário poético buscado, onde a não linearidade narrativa da obra passa a dialogar com sua construção cênico-musical. Na Da construção rítmico-poética, no do jogo entre as palavras e sua rítmica, surgem as cenas.

Conforme Igor Reis Reyner (2011, p. 85), “é da própria escuta que o sujeito se apropria como instrumento de uma nova expressão musical". Acredito que, da mesma forma que a expressão musical é modificada em função do lugar que a escuta ocupa em seu processo de criação, seja ela desenvolvida na composição ou interpretação, também no teatro para bebês ela é um importante instrumento criativo, determinante na elaboração de todas as etapas de criação.

O que pretendo assinalar é que o ator-criador-compositor, dentro dessa poética teatral, trabalha a partir da relação dialógica entre o material sonoro-emocional coletado e o desenvolvimento da atividade de escuta.

Por outro lado, a experiência interativa entre o público dos bebês e a obra assemelha-se à relação que se dá entre mãe/pai-bebê, nos primeiros jogos sonoros-emocionais entre ambos: ela é resultado de uma experiência de afetação que acontece num espaço-tempo determinado.

Sobre a relação da experiência afetiva e subjetiva dos bebês a partir dos estudos de Daniel Stern, os autores Carlos Augusto Peixoto Junior e Márcia Arán afirmam: "quando experienciamos afetos, assim como quando experienciamos uma música, estamos "no tempo", no fluxo do tempo. Trata-se de uma experiência temporal na qual as mudanças desdobram-se no presente, criam a experiência" (2011, p. 743).

\section{Uma experiência de alteridade criativa - o jogo e a escuta na cons- trução dramatúrgica cênica-musical}

A experiência integra uma relação de temporalidade sonora-afetiva, está ligada ao conceito de Pathos - algo de novo que nos acontece. "Se a experiência é o que nos acontece, e se o sujeito da experiência é um território de passagem, então a experiência é uma paixão" (LARROSA, 2011, p. 26).

Da mesma forma, a experiência deve fazer parte da construção do vínculo desenvolvido entre o intérprete e o bebê, pelo chamado 'princípio de alteridade'. Alteridade como princípio que se relaciona a "algo outro, algo completamente outro, radicalmente outro", mas que repercute em mim, "algo que não pode estar capturado ou previamente apropria- 
do nem por minhas palavras, nem por minhas ideias, nem por meus sentimentos, nem por meu saber, nem por meu poder, nem por minha vontade, etc" (LARROSA, 2011, p. 6).

Alteridade da experiência, ou experiência da alteridade, essa é a atitude almejada por um ator-diretor-criador diante do público dos bebês. Aquilo que vibra entre ambos, a própria experiência deve ser o leitmotiv da criação.

O 'princípio de subjetividade' (a experiência é sempre subjetiva) ou chamado 'princípio de transformação' (sujeito sensível, aberto à sua própria transformação) de Larrosa $(2011$, p. 7) associa a experiência ao seu próprio movimento, à sua vibração; é aí "onde se dá a experiência, onde a experiência tem lugar". A experiência também relaciona-se ao chamado 'princípio da incerteza, "não se pode saber de antemão qual vai ser o resultado de uma experiência, onde pode nos conduzir, o que vai fazer de nós. Isso porque a experiência não tem a ver com o tempo linear da planificação, da previsão, da predição, da prescrição, senão com o tempo da abertura" (LARROSA, 2011, p. 19), o tempo do contínuo desenvolvimento da escuta.

No teatro, assim como no teatro para bebês, o ator e a obra devem ser um só território aberto ao encontro; a matéria e o meio para a ação imaginante em contínuo diálogo, pois "o que se experimenta na imaginação é a alteridade que fundamenta a compreensão" (MOTA, 2014, p. 38). Segundo G. Bachelard (1978), a criação está relacionada ao ato de apercebimento, de compreensão do outro, princípio da alteridade. "O movimento para a ficção, para o poético, que se encontra no percurso crítico de Bachelard, revela a amplitude do projeto de sua obra: o desvelamento da estrutura da compreensão indissociada da estrutura da criatividade" (MOTA, 2014, p. 27).

A partir daí cria-se um espaço potencial como um lugar de passagem, transitório, efêmero, mas presente. $\mathrm{O}$ teatro como o lugar do jogo, apresenta-se como espaço transicional. E é por meio do jogo que o indivíduo investe a sua atenção total no aqui e agora. Essa relação acontece através da partilha sem a necessidade de uma explicação, acontece pela experiência da presença, aquela que Winnicott $(1975$, p. 78$)$ define através do brincar no tempo e no espaço, como sendo o uni lugar entre o bebê e a mãe, que propicia a sensação de continuar a ser, pois o brincar está "a serviço da comunicação consigo mesmo e com os outros". Sobre as origens da criatividade como lugar de desenvolvimento do "espaço potencial", Richard Schechner afirma:

Winnicott localizava as origens da criatividade e da ilusão no jogar. A experiência de satisfação enraizada na ilusão e no jogar é inerente à arte, à religião e a toda a cultura. Logo, teorizava que o espaço e as experiências de transição primeiramente explorados entre mãe e filho são a base da vasta superestrutura de cultura (SCHECHNER, 2012, p. 107).

No teatro para bebês essa experiência de constituição do espaço potencial, que acontece na cena através do trabalho do intérprete, edifica um novo espaço transicional, aquele que é vivenciado entre a obra de arte e o bebê, ocupando esta, por sua vez, uma nova possibilidade de construção imagética entre a criança e seus pais. O adulto, na qualidade de observador desse encontro e uma vez inspirado no universo da primeira infância, é conduzido a um novo espaço potencial, sendo o próprio teatro o objeto transicional entre 
eles.

O espaço potencial pode ser denominado também como aquele que é construído a cada nova apresentação da obra entre o intérprete e o público. Existe a partir da troca de estados de presença entre ambos. Existe na alteridade do sentir, do estar, do compartilhar a experiência. Winnicott afirma:

É com base no brincar, que se constrói a totalidade da existência experiencial do homem. Não somos mais introvertidos ou extrovertidos. Experimentamos a vida na área dos fenômenos transacionais, no excitante entrelaçamento da subjetividade e da observação objetiva, e numa área intermediária entre a realidade interna do indivíduo e a realidade compartilhada do mundo externo aos indivíduos (WINNICOTT, 1975, p. 107).

A construção dos sentidos no aqui e agora é um dos objetivos do intérprete quando em cena. Refiro-me aos sentidos da presença, da troca, do jogo, do ato de interpretar. A construção desse estado buscado pelo ator é condição inerente ao bebê. $\mathrm{O}$ teatro para bebês poderia se chamar 'teatro inspirado no estado de presença dos bebês'.

O desenvolvimento da escuta está diretamente relacionado com a capacidade de recepção, ou seja, com a necessidade de identificar algo que acontece no 'aqui e agora', que nos afeta, a 'experiência' em si mesma. "Só somos capazes de escutar aqueles que não entendemos, aqueles que não sabemos de imediato o que é que dizem e o que é que querem dizer" (LARROSA, 2014, p. 66). Dessa forma, interessa-me investigar a relação do público com a obra a partir de sua percepção sensorial e imagética imediata e, portanto, a partir do 'acontecimento' artístico, onde "a expectativa e a sugestão podem intensificar notavelmente a imaginação musical e até produzir uma experiência quase perceptual" (SACKS, 2007, p. 43).

O objeto sonoro para um bebê é algo que pertence ao seu mundo imaginário palpável. Quando escuta o som, o bebê manifesta-se no espaço físico como que tocado pelo som. Assim, sua resposta corporal é muitas vezes a de tocar com os dedos o espaço invisível, como se este de fato existisse entre as suas mãos. A partir da relação também física com o objeto sonoro, constrói-se uma atividade de escuta. Segundo Shaeffer, "a fenomenologia aponta para a necessidade de se focalizar a experiência de um corpo em um mundo se a intenção é estudar a percepção". Escutar é imaginar, antes, durante e depois da experiência de recepção do espetáculo. 


\section{O Farol - espetáculo cênico-musical para a primeira infância}

Um excesso de infância é um germe de poema. Gaston Bachelard

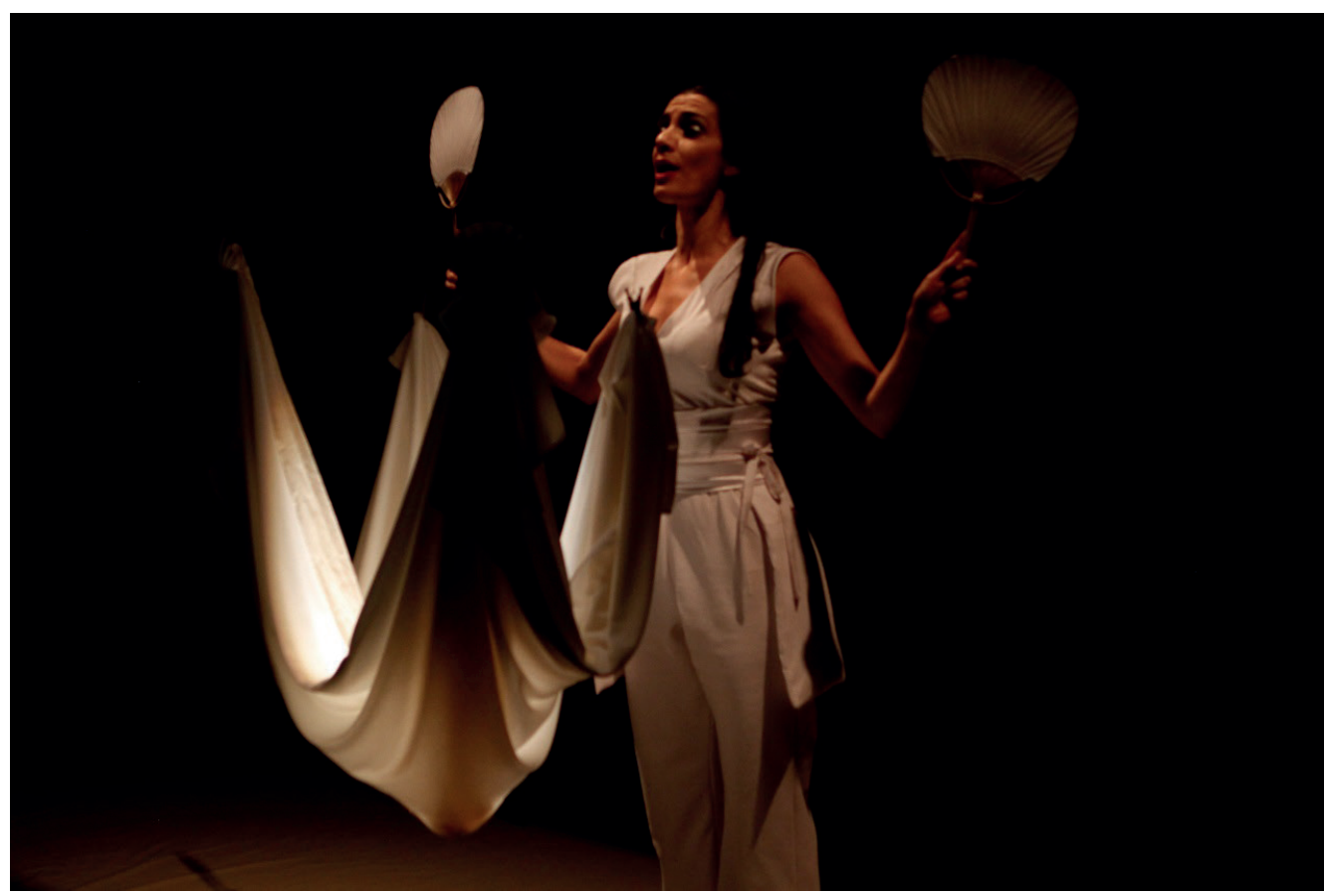

Foto do Espetáculo O Farol ${ }^{3}$ / Fonte: Carlos Laredo

A partir de uma criação dialógica entre a construção dramatúrgica das cenas e sua sonoridade, nasce o espetáculo cênico-musical "O Farol" - resultado prático da pesquisa de mestrado "Teatro para bebês: Processos Criativos, Dramaturgia e Escuta” realizada no departamento de Artes Cênicas da Universidade de Brasília com orientação de Marcus Santos Mota.

Uma das minhas maiores motivações, como artista-criadora dessa poética destinada a bebês, é o contínuo estudo da recepção do espetáculo. As manifestações e afetações desse público em diferentes momentos da obra constroem também o imaginário poético entre intérprete e espectador. A análise desses acontecimentos servirá de estímulo para uma reelaboração da própria obra - considerando-a aberta e inacabada, sempre em contínuo processo de construção.

A relação de recepção entre o intérprete e o público em uma obra surge "a partir das diversas leituras que cada executante imprime em sua interpretação" (APRO, 2006, p. 29), cada qual a partir de seus ritmos próprios de percepção. Paulo Lameiro (2015) afirma: "É importante que as pessoas sintam que o importante da música não é o que está fora de nós, é o que está dentro de nós, pois a música está dentro de nós" ${ }^{4}$. A criação musical teria

3 O espetáculo O Farol teve sua estreia no Teatro Plinio Marcos da Funarte, em Brasília, no dia 30 de julho de 2015. Foram realizadas duas apresentações para grupos de 35 bebês acompanhados por adultos.

4 Para texto completo veja entrevista APÊNDICE A da dissertação "Teatro para Bebês: Processos Criativos, Dramaturgia e Escuta" no repositório da UNB http://repositorio.unb.br/. 
dentro do processo criativo do espetáculo, a função de organizar o material criativo do artista, onde através dela "o devaneio poético, criador de símbolos, dá à nossa intimidade uma atividade polissimbólica” (BACHELARD, 1978, p. 126).

A linguagem musical é escolhida como elemento condutor na elaboração desse processo criativo, inspirado no espectador bebê e em sua relação afetiva entre pai/mãe e de recepção com a obra. Parto do princípio de que através da atividade musical o receptor é cativado a habitar um "espaço de atemporalidade" - princípio de aproximação entre "mito e realidade" (como temática criativa) e do desenvolvimento da escuta. Conforme afirma Maria de Lourdes Sekeff (2007, p. 26), "no exercício da escuta ouvimos o discurso musical, mas também ouvimos a nós mesmos", já que a escuta nos permite ouvir a "fala do outro em nós" (SEKEFF, 2007, p. 26).

Desta forma, acredito que o estudo desses elementos que conformam a relação com a obra de arte a partir do elo emotivo-afetivo entre pais e bebês são fundamentais à atividade de recepção e escuta da mesma.

A atividade de escuta pode-se caracterizar como um dispositivo, elemento-condutor à elaboração de uma obra para bebês. Como pulsão criativa, habita uma paisagem que é emocional e, ao mesmo tempo, sonora. Assim como o músico-ouvinte pode analisar os sons de um determinado ambiente, cabe ao artista-criador reconhecer os elementos que a conformam. "O que o analista da paisagem sonora precisa fazer, em primeiro lugar, é descobrir os seus aspectos significativos, aqueles sons que são importantes por causa de sua individualidade, quantidade e preponderância” (SCHAFER, 1997, p. 25).

\section{A voz e o canto na recepção da obra}

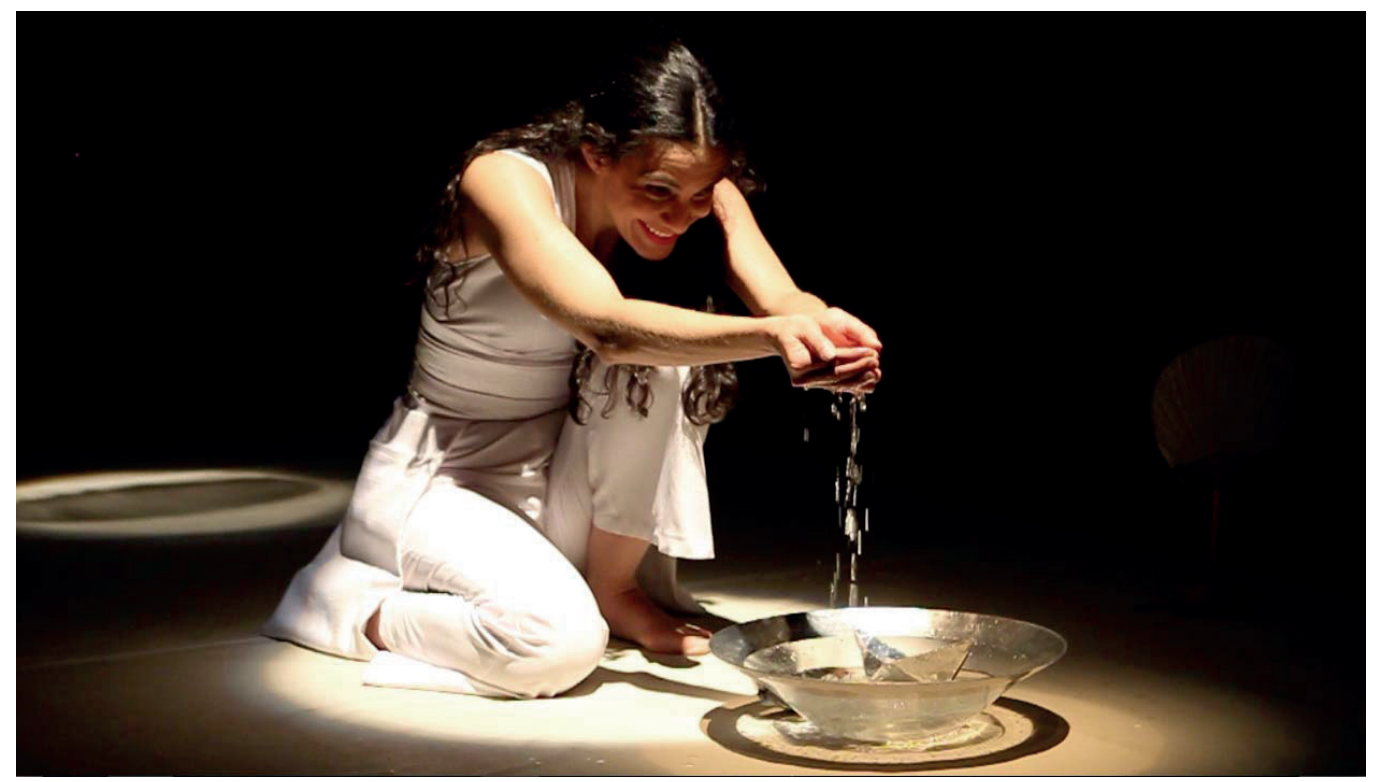

Foto do Espetáculo O Farol ${ }^{5}$ / Fonte: Acervo pessoal Fernanda Cabral.

5 Apresentação do espetáculo O Farol no Teatro Plinio Marcos da Funarte, em Brasília, no dia 30 de julho de 2015. 
O meu primeiro desejo ao elaborar essa obra foi o de iniciar o seu processo criativo a partir da observação do 'ambiente sonoro' comunicativo-emocional entre o bebê e a mãe. Um dos aspectos que pude observar nessa relação parte da preferência do bebê pelos sons acústicos e, em especial, pela voz humana, sendo a de sua mãe o seu principal foco de atenção. "O bebê de fato prefere ouvir a mãe, só porque tem com ela um sentido de sobrevivência, sabe que aquele timbre é a sua casa para sobreviver"' pois, conforme afirma Stahlschmidt (2008, p. 71), "a atividade musical poderia levar mães e bebês a reviver períodos anteriores de sua relação, talvez ainda estabelecidos ao longo da gestação e, com isso, trazer sensações de conforto e bem estar".

O reconhecimento tímbrico da voz materna está diretamente ligado à construção da linguagem e de sua comunicação, já que "os princípios da aquisição da linguagem e do desenvolvimento da competência musical podem ser indistintamente abordados no quadro da interação familiar, como formas de comunicação humana na primeira infância" (RODRIGUES, 2005, p. 64).

Stahlschidt (2008) defende que uma obra musical ou uma canção infantil (canção de ninar) podem trazer dados importantes sobre a formação da linguagem idiomática e emocional do bebê. Reflexão que surge como resultado de seu estudo sobre o lugar da música na relação pais-bebê através de seu trabalho pedagógico de musicalização.

Em seu estudo A. Stahlschidt potencializa e relaciona a constituição de um sujeito em sociedade a partir da atividade musical. Conforme Sandra Trehub (2010, p. 79), "a percepção musical, quando estimulada logo nos primeiros contatos entre o bebê e sua mãe, pode contribuir em seu papel ao longo da vida como um regulador emocional e facilitador de conexões sociais". Uma relação que pode ser estimulada entre pais e bebê desde o seu nascimento, com foco na função do brincar, eixo fundamental em seu desenvolvimento.

Em uma obra musical, melodias se sobrepõem, harmonias se criam, ideias nascem, tomam forma ou se diluem no universo de sons onde se constituíram e, subitamente, um tema surge, é desenvolvido, desaparece e reaparece em sucessivas variações. Assim parece dar-se a criação e consolidação do laço pais-bebê (STAHLSCHMIDT, 2008, p. 15).

Observando a relação de desenvolvimento do bebê, a partir da formação dos sentidos até o uso destes entre ambos (pais e bebê), novas formas de comunicação sonoro-musical são reveladas. A partir do processo de observação da comunicação e formação da linguagem sonora-emocional entre o bebê e a mãe-pai, muito se pode aprender sobre a recepção-sonora do bebê em cena, assim como obter ferramentas criativas à elaboração da obra.

O desenvolvimento da escuta corporal e sonora é fundamental para a mãe que relaciona esses dois elementos como quase indissociáveis à construção da sua comunicação

6 Para texto completo veja entrevista APÊNDICE A da dissertação “Teatro para Bebês: Processos Criativos, Dramaturgia e Escuta” no repositório da UNB http://repositorio.unb.br/. 
com o bebê. A capacidade do desenvolvimento de uma escuta ativa - aquela que a mãe exerce em seu cotidiano para compreender as necessidades básicas do bebê - está relacionada ao conceito de alteridade como formadora da própria linguagem.

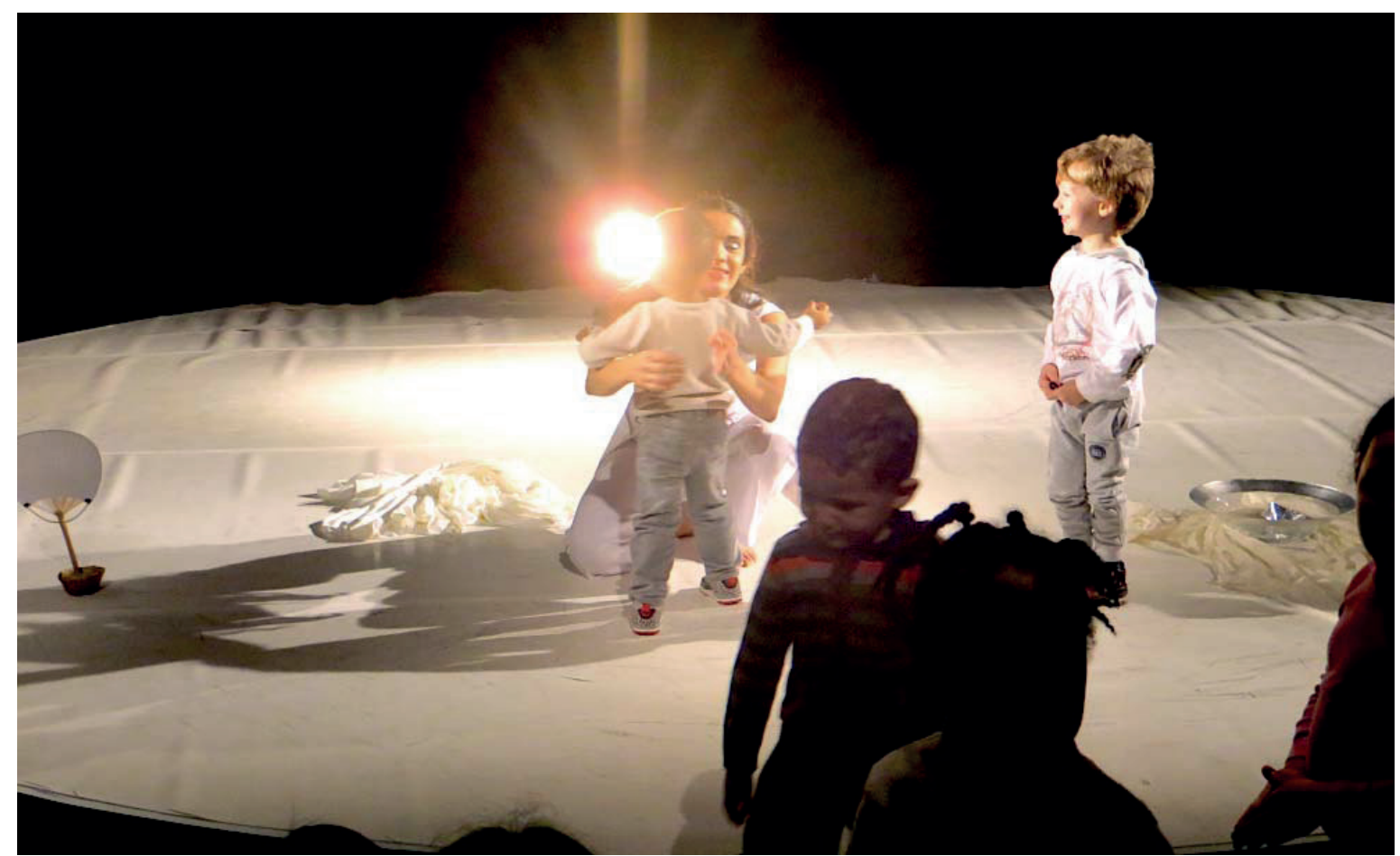

Foto do Espetáculo O Farol ${ }^{7}$ Fonte: Acervo pessoal Fernanda Cabral.

O cantar, como experiência do encontro comigo mesma e com os temas que conformam a minhas lembranças e recriam a primeira infância, ocupa um lugar especial no meu trabalho de interpretação na obra $O$ Farol, pois "música e sujeito parecem fundir-se, evocando a importância da experiência musical como uma das formas de compreender a relação primordial do sujeito com o Outro" (STAHLSCHMIDT, 2008, p. 238). É através da comunicação dessa história pessoal, de sua narração por meio de sons, que o público dos bebês se sentirá conectado e atraído pelo intérprete.

A voz humana e o canto são referências importantes para um bebê, especialmente a voz materna. Segundo Daniel Stern (2011, p. 82), "a essa idade o bebê é particularmente sensível e se sente cativado pelos humanos e pelo que estes fazem. Se dá conta da corrente espacial da conversa, porque a voz humana significa muito para ele". Stern se refere aos seis meses de idade aproximadamente, embora não se possa aferir padrões de semelhanças generalizadas das capacidades de percepção de um bebê, já que essas variam enormemente segundo o contexto e os estímulos recebidos durante o seu desenvolvimento. No entanto, pode-se dizer que o principal 'objeto sonoro' de um bebê é primeiramente a voz da mãe, do pai ou dos que mais próximos se encontram dele, e que o bebê sempre pres-

7 Para mais informações veja: http://compagnie-acta.org/?page id=849. Apresentação da peça no $7^{\circ}$ Festival Premières Reencontres em Val d'Oise - Villiers-Le-Bel (Paris), realizado entre os dias 19 de março e 9 de abril de 2016 com apoio do FAC - Fundo de Apoio à Cultura do DF. 
tará mais atenção ao som vocal do que aos demais sons dentro de um ambiente sonoro. A canção, quando estimulada desde cedo entre pais e bebês, pode exercer um importante papel em sua comunicação afetiva e social com o mundo.

Segundo Jorge Larrosa (2014, n.p.), a experiência pode ser nomeada como 'cantos', "cantos apaixonados, intensos, prementes, emocionados e emocionantes, que têm a experiência como tema ou como motivo principal, se entendermos os termos 'motivo' e 'tema' em seu sentido musical". Para Mircea Eliade (2013, p. 28), "os cantos, em sua maioria, são mitos de origem”. A 'experiência' abriga em seus cantos de origem memórias pessoais. A recriação dos mitos da primeira infância, dos mitos de origem, é um veículo para a descoberta da experiência de interioridade, fundamental ao artista em seu processo de criação da obra feita para bebês. Segundo Federico García Lorca (2000, p. 84), nas canções de ninar "a melodia, muito mais que o texto, define os caracteres geográficos e a linha histórica de uma região e assinala, de maneira fundamental, momentos definidos de um perfil que o tempo apagou".

Criar conhecimento é comunicar-se. O bebê necessita se comunicar continuamente com o que o rodeia, e é também através dos sons que cria o seu próprio território sonoro particular. É aí onde se desenvolve parte da sua identidade e uma maneira particular de se relacionar com o mundo ao redor. Procurei, dentro da construção sonora-musical dessa obra, colocar-me nesse lugar da descoberta dos sons e temas musicais, buscando a origem dos meus próprios sons, os que produzo como compositora, mas também como intérprete. "Quando evocamos a canção ou as vocalizações em nós, não apenas criamos o território, o em-casa, que protege das forças caóticas, como também colocamos para funcionar algo fugidio, como uma melodia que leva para além dos limites de segurança" (OBICI, 2008, p. 79). Assim, a criação musical é também a construção de uma temporalidade de ação que orienta o intérprete na cena. Ali, "a duração não delineia uma dimensão formal em que se escoa o ser, mas é, ao mesmo tempo, ser e experiência do ser”. (LÉVINAS, 1997, p. 72).

Por meio da comunicação vocal, o intérprete estabelece uma relação mais próxima à díade mãe/pai e bebê. Acredito também que, pelo fato de nessa obra a presença da canção e da voz ocuparem um espaço de relevância em sua composição musical, foi possível uma maior aproximação com o público.

A voz da mãe e a música podem ser percebidas pelo bebê como parte da linguagem afetiva. A experiência do cantar é uma aproximação a esse lugar, ela desenvolve tanto na mãe quanto no bebê uma ampliação da capacidade da escuta durante a apresentação da obra.

Finalizo essa reflexão remetendo-me às impressões de uma das organizadoras do festival Premières Reencontres, a diretora Agnès Desfosses, sobre a sua experiência particular de recepção da obra $O$ Farol nessa ocasião: "o que mais me chamou a atenção foi a maneira de acolher o público desde o início até o final do espetáculo. Há muita sensibilidade na voz e na maneira de cantar. O que se transmite é a paz, a mesma que permite ao bebê

8 Citação retirada do DVD parte do livro “Tremores - Escritos sobre experiência”. 
dormir, após o canto de sua mãe." O meu principal objetivo foi elaborar uma obra em que a música fosse o fio condutor da criação e a canção aparecesse de forma a aproximar bebês e adultos, embalando-os pelo encontro teatral.

\section{Considerações finais}

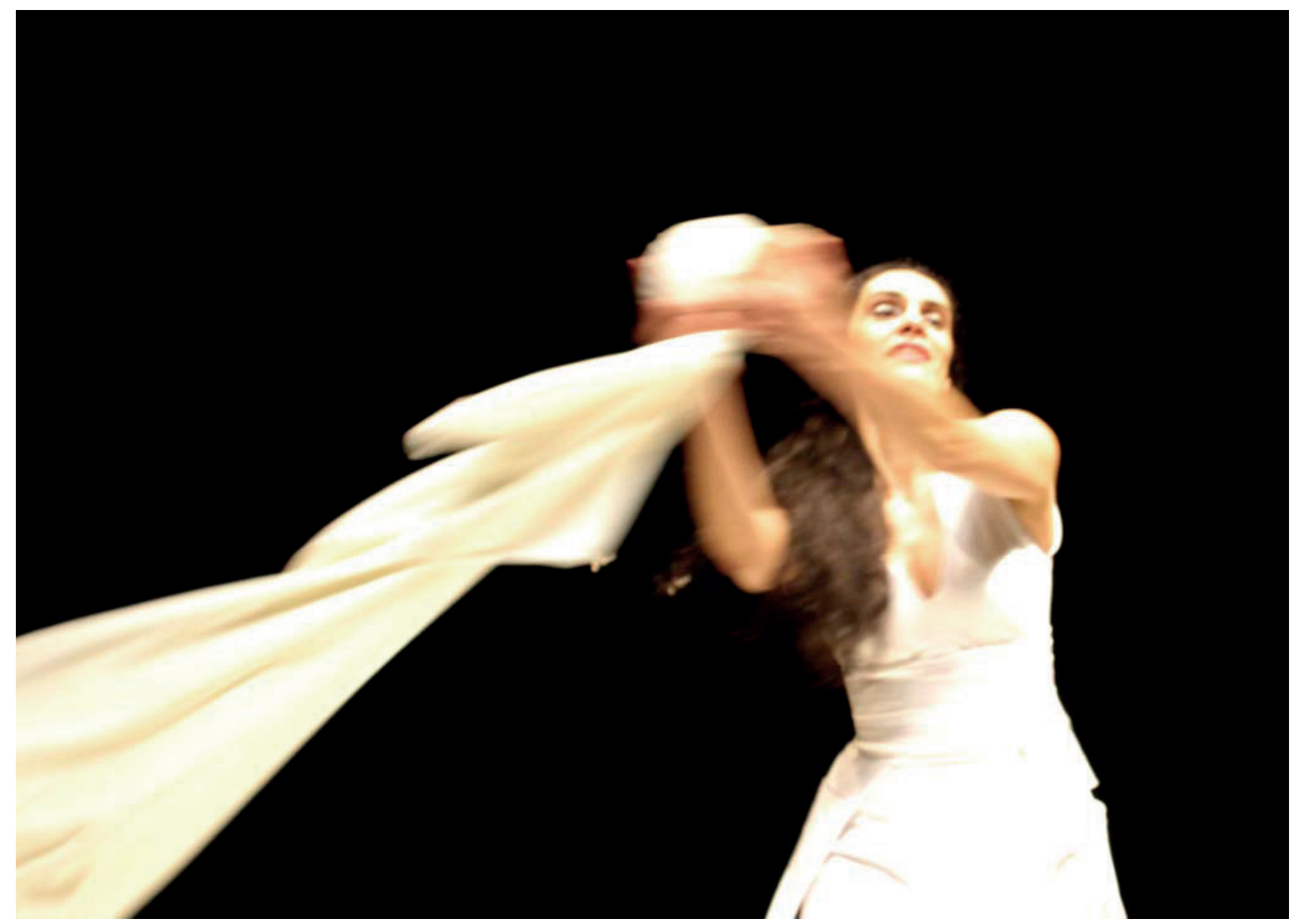

Foto do Espetáculo O Farol ${ }^{9}$ / Fonte: André Amaro

O teatro para bebês pode ser a primeira experiência artística de um bebê como espectador. Por essa razão, o seu primeiro encontro ou "batismo teatral" deve ser realizado com a devida delicadeza. No processo de criação do espetáculo O Farol, o sonoro-musical se desenvolveu na criação dramatúrgica do espetáculo, como articulador dos aspectos simbólicos e imagéticos da própria obra, compondo assim sua dramaturgia musical - a fim de estreitar os laços de recepção da obra entre público e intérprete.

Considero a criação de uma dramaturgia musical um 'território de passagem', onde "o que move o homem é a ideia de transitoriedade" (PIORSKI, 2015, n.p.). Nesse lugar, o particular, o específico do artista-criador irá conformar o seu 'canto próprio', atraindo o interesse do público. Daí a importância da construção de uma dramaturgia calcada nas ressonâncias particulares do artista com o universo da primeira infância. A conquista de um território expressivo no teatro se dá no exercício dessas qualidades particulares do

9 Apresentação do espetáculo O Farol (Cia. Studio Sereia) no Teatro Plinio Marcos da Funarte, em Brasília, no dia 9 de julho de 2016 dentro da programação do III Festival Primeiro Olhar do DF. 
ator-intérprete. Como encontrar essas qualidades? A resposta pode estar na construção dessa linguagem cênico-sonora. Foi o que busquei fazer e o que se vê no resultado final: pais e bebês aproximados por uma vida sonora poeticamente construída no espaço teatral.

No processo de criação do espetáculo $O$ Farol, comprova-se que a relação dialógica composicional entre o aspecto sonoro musical e a própria elaboração dramatúrgica da obra é estimulada pela própria experiência do artista-criador dentro desse jogo lúdico e imaginativo. E é a partir daquilo que ele escuta nesse processo que a criação surgirá, sendo esta escuta o veículo para a elaboração dramatúrgica-musical da obra, como também uma ferramenta fundamental na recepção por parte do público dos bebês.

O processo de criação no teatro para bebês parte deste lugar, da experiência por meio da qual se observam as infinitas dimensões da poética já presentes na cotidianidade dos bebês, neste "outro". Faz-se necessária a valorização de uma construção do saber a partir das capacidades inatas destes. O bebê não é uma página em branco "ao contrário da ideia do bebê vindo ao mundo como uma tabula rasa, os bebês são ouvintes sofisticados desde a mais tenra idade" (ILARI, 2002, p. 88). O bebê traz em sua memória biológica características de uma sensibilidade singular, ao mesmo tempo que constrói sua identidade a partir da relação de afeto com o outro, como base para sua comunicação emocional e social.

Parto do princípio de que o bebê está completamente apto a fruir com o espetáculo desde sua vasta capacidade de entendimento, a partir de sua percepção sensorial, emocional, mítico-poética e imagética da obra que foi feita e pensada para ele em sua ampla dimensão. Acredito que a comunicação entre o público e a obra é potenciada quando existe uma construção sonora-musical em seu processo criativo, quando em sua poética existe uma poética da escuta, do silêncio, do imaginário que se constrói entre ambos no encontro cênico, perpetuado pela contínua experiência do brincar.

\section{Referências}

APRO, Flávio. Interpretação Musical: Um universo (ainda) em construção. In: LIMA, Sonia Albano de Lima (Org). Performance e Interpretação Musical: Uma prática interdisciplinar. São Paulo: Musa Editora, 2006.

BACHELARD, Gaston. A poética do Devaneio. Tradução Antonio de Pádua Danesi. Brasília Martins Fontes, 1996.

A poética do Espaço. Tradução Antonio de Pádua Danesi. São Paulo: Abril Cultural, 1978.

BARBIER, René. A pesquisa-ação. Série Pesquisa em Educação, v.3. Brasília: Plano, 2002. BEAINI, Thais Curi. A Memória: Medida Ontológia do Cosmos. São Paulo: Editora Palas Athena, 1989. . Máscaras do Tempo. Vozes. Petrópolis: 1995.

CABANIS, Anne-Françoise; JANNELLE, Chantal. La création et Le petit enfant. Allée de la Ferme, França: Editions de l'Aube, 1993.

CHION, Michel. La audiovisión - Introducción a un análisis conjunto de la imagen y el 
sonido. Barcelona: Ediciones Paisós Ibérica, S.A., 1993.

DESGRANGES, Flávio. Pedagogia do Teatro: Provocações e dialogistmo. São Paulo: Hucitec, 2011.

ELIADE, Mircea. Imagens e Símbolos: Ensaio sobre o simbolismo mágico-religioso. São Paulo: Martins Fontes, 1991.

Mito e Realidade. São Paulo: Perspectiva, 2013.

ILARI, Beatriz Senoi. Bebês também entendem de música: a percepção e a cognição musical no primeiro ano de vida. In: Revista da ABEM, Porto Alegre, V. 7, 83-90, set. 2002.

LARROSA, Jorge. Tremores: Escritos sobre experiência. Belo Horizonte: Autêntica Editora, 2014.

Experiências e alteridade na educação. In: Revista Reflexão e Ação, Santa Cruz do Sul, v.19, n2, p.04-27, jul./dez. 2011.

LORCA, Federico García - Seleção, tradução e notas de Marcus Mota. Conferências. Brasília: Editora Universidade de Brasília: São Paulo: Imprensa Oficial do Estado, 2000.

LEHMANN, Hans-Thies. Teatro pós-dramático. São Paulo: Cosac Naify, 2011.

LÉVINAS, Emmanuel. Entre nós: Ensaio sobre a Alteridade. Petrópolis: Editora Vozes, 1997.

MOTA, Marcus. Imaginação e Morte: Estudos sobre a representação da finitude. Brasília: Editora Universidade de Brasília, 2014.

OBICI, Giuliano Lamberti. Condições da escuta - Mídias e Territórios Sonoros. Rio de Janeiro: 7 Letras, 2008.

PEIXOTO, Carlos Agusto Junior; ARÁN, Márcia. O lugar da experiência afetiva na gênese dos processos de subjetivação. In: Revista PSICOLOGIA USP, São Paulo, 2011, 22(4), 725-745.

PIORSKI, Gandhy. Náufragos e Piratas do Aprendizado. In: MEIRELLES, Renata (Org). Território do Brincar-Diálogo com Escolas. São Paulo: Instituto Alana, 2015.

REYNER, Igor Reis. Pierre Schaeffer e sua teoria da escuta. Porto Alegre: Opus, v. 17, n. 2, p.77-106, 2011.

RODRIGUES, Helena. A festa da música. In: Revista da Faculdade de Ciências Sociais e Humanas n. 17, Lisboa, Edições Colibri, 2005, p. 61-80. Disponível em: <http://run. unl.pt/handle/10362/8039>. Acesso em: 1 jan. 2016

SACKS, Oliver. Alucinações musicais: Relatos sobre a música e o cérebro. São Paulo: Companhia das Letras, 2007.

SARRAZAC, Jean Pierre. O Futuro do Drama. Porto: Editora Campo das Letras, 2006.

SCHAFER, R. Murray. A afinação do mundo. São Paulo: Editora Unesp, 1997.

O ouvido pensante. São Paulo: Editora Unesp, 1991.

SCHAEFFER, Pierre. Tratado de los objetos musicales. Madrid: Alianza Editorial, 2003.

SCHECHNER, Richard. Performance e Antropologia de Richard Schechner. In: LIGIÉRO, Z. (ORG). MAUAD X. Rio de Janeiro: Editora Ltda, 2012.

SEKEFF, Maria de Lourdes. Da música, seus usos e recursos. São Paulo: Editora Unesp, 2007.

SOUZA, João Wesley de Souza. Prospecção e construção poética - Considerações sobre 
algumas possíveis vertentes do processo de criação artística. In: Anais de Pesquisa PPG IA UNESP 2015 - Edição Internacional. Disponível em: <http://iaunespjornada2015.blogspot.com.br/2015/06/anais.html>. Acesso em: 17 dez.2015.

STERN, Daniel. Diario de un bebé. Barcelona: Paidós, 2011.

TREHUB, Sandra. In the beginning: A brief history of infant music perception. University of Toronto and Université de Montral, Toronto, 2010. Disponível em: <http://msx. sagepub.com/content/14/2_suppl/71.abstract>. Acesso em: 1 jan. 2016.

WINNICOTT, D.W. O Brincar e a Realidade. Rio de Janeiro: Imago, 1975. 